\title{
THE PEDAGOGY of ARGUMENTATION in SCIENCE EDUCATION: SCIENCE TEACHERS' INSTRUCTIONAL PRACTICES
}

*Yasemin Ozdem-Yilmaz, $\mathrm{PhD}$ (Corresponding Author)

Gaziosmanpasa University, Faculty of Education

Department of Elementary Education, Tokat/ Turkey

Phone: +90 (356) 2521616

E-mail: yasemin.ozdem@gop.edu.tr

Jale Cakiroglu, Prof. Dr.

Middle East Technical University, Faculty of Education

Department of Elementary Education, Ankara/ Turkey

Phone: +90 (312) 2104051

E-mail: jaleus@metu.edu.tr

Hamide Ertepinar, Prof. Dr.

Istanbul Aydin University, Faculty of Education

Department of Elementary Education, Istanbul/ Turkey

E-mail: hamideertepinar@aydin.edu.tr

Sibel Erduran, Prof. Dr.

University of Oxford, Department of Education

Oxford, United Kingdom

National Taiwan Normal University, Graduate Institute of Science Education

Taipei, Taiwan

University of Limerick, EPI-STEM, The National Centre for STEM Education

Limerick, Ireland

Email: sibel.erduran@education.ox.ac.uk 


\title{
THE PEDAGOGY of ARGUMENTATION in SCIENCE EDUCATION: SCIENCE TEACHERS' INSTRUCTIONAL PRACTICES
}

\author{
Yasemin Ozdem-Yilmaz $^{1}$, Jale Cakiroglu ${ }^{2}$, Hamide Ertepinar ${ }^{3}$, Sibel Erduran ${ }^{4}$
}

\begin{abstract}
Argumentation has been a prominent concern in science education research and a common goal in science curriculum in many countries over the past decade. With reference to this goal, policy documents burden responsibilities on science teachers, such as involving students in dialogues and being guides in students' spoken or written argumentation. Consequently, teachers' pedagogical practices regarding argumentation gain importance due to their impact on how they incorporate this scientific practice into their science classrooms. In this study, therefore, we investigated the instructional strategies adopted by science teachers for their argumentation-based science teaching. Participants were 1 elementary science teacher, 2 chemistry teachers, and 4 graduate students, who have a background in science education. The study took place during a graduate course, which was aimed at developing science teachers' theory and pedagogy of argumentation. Data sources included the participants' video-recorded classroom practices, audiorecorded reflections, post-interviews, and participants' written materials. The findings revealed three typologies of instructional strategies towards argumentation. They are named as argumentation specific pedagogical knowledge, meta-level pedagogical knowledge specific to argumentation, and meta-strategic knowledge specific to argumentation. Based on the findings of this study, it was concluded that through a cycle of reflective practice, the teachers adapted and developed instructional strategies to promote argumentation in their teaching practice. Moreover, the study provided a detailed coding framework for the exploration of science teachers' instructional practices while they are implementing argumentationbased lessons.
\end{abstract}

Keywords: Argumentation, Teacher education, Pedagogical content knowledge, Instructional strategies

\section{INTRODUCTION}

Argumentation has been an indispensable part of science education in schools over the past decade (Erduran \& Jimenez-Aleixandre, 2012; Erduran, Ozdem, \& Park, 2015; Lee, Wu, \& Tsai, 2009; Science Teacher Education Advanced Methods [S-TEAM], 2010). As a result, the reform and policy documents on science education called for students to practice argumentation in science classrooms, especially in elementary grades (e.g. Commission, EACEA, Eurydice, 2012; Ministry of National Education in Turkey [MNE], 2013; National Research Council [NRC], 2012). The rationale was that student engagement in scientific argumentation enhances their conceptual, epistemological and methodological understanding about science (Sampson \&

\footnotetext{
${ }^{1}$ (Corresponding Author) Gaziosmanpasa University, Faculty of Education, Turkey, yasemin.ozdem@gop.edu.tr

${ }^{2}$ Middle East Technical University, Faculty of Education, Turkey, jaleus@metu.edu.tr

${ }^{3}$ Istanbul Aydin University, Faculty of Education, Turkey, hamideertepinar@aydin.edu.tr

${ }^{4}$ University of Oxford, Department of Education, United Kingdom, sibel.erduran@education.ox.ac.uk
} 
Blanchard, 2012), and it supports students' enculturation into the practices of science (Dawson \& Venville, 2010; Jiménez-Aleixandre \& Erduran, 2008).

This focus on argumentation has consequently prompted research that aims to promote argumentative practices in the science classrooms (Bybee, 2011; Driver, Newton, \& Osborne, 2000; Duschl \& Osborne, 2002; Jiménez-Aleixandre \& Erduran, 2008; NRC, 2012). As part of this effort, science teachers are provided with professional development opportunities to improve their pedagogical knowledge in the context of teaching argumentation. For example, research has been devoted to developing instructional strategies (Duschl, Ellenbogen, \& Erduran, 1999; Kuhn \& Reiser, 2006; Osborne, Erduran, \& Simon, 2004) or teaching materials including technology enhanced learning tools (Bell \& Linn, 2000; Clark \& Sampson, 2007; Sandoval \& Reiser, 2004) and to designing professional development workshops for the development and practice of instructional strategies (Simon, Erduran, \& Osborne, 2006; Simon \& Johnson, 2008; Simon, Richardson, Howell-Richardson, Christodolou, \& Osborne, 2010); the argumentation theory is thus gradually introduced into teacher education programs (Tümay, 2008). Despite these contributions, the science teachers still consider argumentation as a challenging practice (Jiménez-Aleixandre, 2008; Simon, Erduran, \& Osborne, 2006; Zohar, 2008). For instance, recent research has showed that teachers struggle with distinguishing the structural components and the dialogic nature of argumentation during classroom discussions, and they have difficulty in posing the appropriate questions to help the students engage in argumentation (McNeill \& Knight, 2013).

Given the above, it is important for teachers to know the pedagogical strategies related to integrating argumentation in the classroom; the relevant research and the policy documents, however, differ on what teachers really need to know about the pedagogy of argumentation and which instructional strategies increase argumentation in science classes (Evagorou \& Dillon, 2011). Some scholars have focused on the instances in which the teacher's contribution enabled and supported oral argumentation about scientific (Jiménez-Aleixandre \& Erduran, 2008; Simon, Erduran, \& Osborne, 2006) and socioscientific issues (Evagorou \& Dillon, 2011; Dawson \& Venville, 2010), while some others have investigated the ways through which teachers have analysed students' written argumentation (McNeill \& Knight, 2013; Sadler, 2006). Other research has investigated teachers' questioning strategies in supporting classroom discourse with a particular focus on scientific argumentation (Martin \& Hand, 2009; McNeill \& Pimentel, 2010). Yet, a comprehensive framework on the pedagogical strategies that result in argumentation at different quality levels has not been provided.

In this study, therefore, we extend the research mentioned above to consider the instructional strategies that the teachers can adopt for their argumentation-based science teaching. Providing a comprehensive list of pedagogical strategies is important because teachers and researchers may initiate, support, and leverage argumentation in science classrooms by means of these instructional strategies. Studies regarding teachers' role in argumentation have suggested that science teachers need to have a range of appropriate pedagogical strategies and materials as well as pedagogical knowledge on argumentation in order to integrate argumentation 
in their science teaching (Duschl \& Osborne, 2002; Osborne, Erduran, \& Simon, 2004; Zohar, 2008).

Informed by the research on teachers' role in argumentation in science education, we worked with science teachers and graduate students who will be the future teacher educators to investigate the instructional strategies used for and in argumentation by science teachers. In this study, we focus on videos of classes in which argumentation strategies were used and the lesson plans prepared by science teachers. We ask the research question: What are the instructional strategies specific to argumentation that teachers make use of when they plan and implement classroom practices related to argumentation during a graduate course?

\section{THEORETICAL FRAMEWORK}

\section{Argumentation as a Goal of Science Education}

Argumentation is a kind of discourse through which arguments are individually and collaboratively constructed and evaluated in light of empirical or theoretical evidence, alternative views, justifications and rebuttals (Jiménez-Aleixandre \& Erduran, 2008; Kuhn, 1993). An argument refers to the content or substance of the argumentation. In Toulmin's (1978) definition, an argument is comprised of the elements of claim, data, warrants, and supporting evidence. In this structural definition of arguments, claim is an answer to a scientific question; evidence might be measurements and observations in relation to the claim; and warrants or justifications serve as the link between claims and evidence to clarify why that specific evidence supports a claim (Toulmin, 1978). These pieces are considered as components of an argument. To engage in argumentation, students should be able to bring together these components in a meaningful way, to debate with and persuade peers and to critique other arguments in ways similar to the way scientists engage in academic debates (Driver, Newton, \& Osborne, 2000; McNeill et al., 2016).

The constructivist views of science education emphasize that argumentation is a social constructivist learning practice (Driver, Newton, \& Osborne, 2000; Jiménez-Aleixandre, 2008; Newton, Driver, \& Osborne, 1999; Walker \& Sampson, 2013). For example, JiménezAleixandre (2008) argues that argumentative environments are constructivist because of their emphasis on the evaluation of knowledge claims. Similarly, Osborne (2005) claims that argumentation leads to significant gains in students' epistemological understanding about science in such a way that students develop not only a conceptual understanding of science but also an understanding of how scientific knowledge is constructed. As an example, Kim and Song (2006) reported that during argumentation, middle school students, who were performing open-ended inquiry tasks, showed improvement in their interpretation and methods of experiments. Sampson, Grooms and Walker (2009) found that Argument Driven Inquiry (ADI) enabled students gain scientific literacy and allowed them "to develop scientific habits of mind, provide evidence for explanations, and think critically about suggested alternatives" (p.47).

In addition to the above, there are several factors that have an influence on students' dialogues and the arguments they constructed. The context, for example, which includes the 
social dialogical opportunities and the learning environment allowing space for argumentation, the contextualization of the subject matter and the instructional strategies that teachers employ are among these factors (Kolsto \& Ratcliffe, 2008; Simonneaux, 2008). As Berland and Hammer (2012) state, the incorporation of argumentation into science lessons requires the organization of a relevant teaching and learning context. However, most of the teachers lack pedagogical content knowledge and the necessary resources to design argumentation-based lessons and mediate the learning environment for argumentation (Duschl, 2008; Osborne, Erduran, \& Simon, 2004). This leads to argumentation being considered as a challenging practice for many science teachers (Jiménez-Aleixandre, 2008; Simon, Erduran, \& Osborne, 2006; Zohar, 2008). Thus, the challenges that teachers face should be acknowledged and teachers should be informed about argumentation and assisted in improving their pedagogy of argumentation.

\section{Teachers' Pedagogical Content Knowledge for Argumentation in Science Education}

Teachers' pedagogical content knowledge (PCK) is described by Shulman (1986) as the knowledge of instructional strategies and representations, and the knowledge of student conceptions. PCK in terms of knowledge of instructional strategies refers to "the ways of representing and formulating the subject that make it comprehensible to others" (Shulman, 1986, p.9). Several researchers argue that this definition of PCK for science covers the PCK for disciplinary strategies as well, such as scientific inquiry and argumentation (Davis \& Krajcik, 2005; Knight-Bardsley \& Mcneill, 2016; Osborne, 2014). In this study, we also focused on teachers' PCK for argumentation in terms of knowledge of instructional strategies to support students in this authentic disciplinary practice of science.

In particular, teachers are encouraged to develop appropriate PCK in order to promote students' argumentation (Osborne, Erduran, \& Simon, 2004). The research around teachers' practices for scientific argumentation (Evagorou \& Dillon, 2011; McNeill \& Krajcik, 2008; Osborne, Erduran, \& Simon, 2004) provides an understanding of the instructional strategies that are used by science teachers. For example, the studies by Simon, Erduran, and Osborne (2006) and Jiménez-Aleixandre and Erduran (2008) focused on cases in which the teacher's contribution enabled and supported oral argumentation in elementary schools. Teachers who value talking and listening to others tend to give privilege to modelling and exemplification, position themselves within an argument and justify their position using evidence, construct and evaluate an argument along with counter-arguments and debate, and reflect upon the argumentation as a way of knowing. In a study by Patronis, Potari, and Spiliotopoulou (1999), researchers reported that teachers' intervention and evaluation of students' arguments through questioning may offer opportunities for students to become more involved in the issue of debate and to validate their previous arguments in a more integrated and detailed way. An autobiographical study by Mork (2005) revealed a typology of a teacher's role in the management of argumentative role-play debates. As a result, the researcher identified various interventions that teachers can employ in argumentative activities. For example, challenging the validity of information, extending the range of debate, keeping the debate on track and alive, promoting students' involvement and 
focusing on debate techniques are the interventions found in the typology (Mork, 2005). McNeill and Pimentel (2010) observed that the "teacher's use of open questions appeared to encourage students to construct and justify their claims using both their scientific and everyday knowledge" (p.225). They further reported that the teacher's explicit connections to previous students' comments seemingly encouraged students to think about alternative views and reflect on the thinking process (McNeill and Pimentel, 2010). A longitudinal case study by Martin and Hand (2009) also found similar results regarding questioning strategies. The researchers found that the teacher's use of open questions had a positive impact on students' participation such that students provided evidence for claims and offered rebuttals during argumentation. Yet, there are more to this set of strategies.

There are strategies supported by research findings that are crucial to metacognition in the form of either meta-strategic or metacognitive awareness (Garcia-Mila \& Andersen, 2008). For example, Kuhn and Udell (2003) proposed that for the use of argumentation strategies to increase, there is a need for consistent practice and development of the associated skills as well as an enhanced meta-level consciousness of task goals. Zohar (2008) also highlighted the aspect of epistemological meta-knowing and suggested the use of oral contributions by the teacher for promoting argumentation, as well as the use of writing probes to focus on the need to explain how we know what we know and why one knows, to justify arguments with evidence and reasoning, or to think about alternative viewpoints and evaluate them. Regarding teachers' oral contribution or written probes, the researcher proposed that the "how" component of metastrategic knowledge regarding argumentation can be made explicit through emphasizing the way sound argumentation should be carried out in a science classroom (Zohar, 2008).

The studies, in sum, illustrate that science teachers' roles in argumentation involve modelling and guiding inquiry (Jiménez-Aleixandre, 2008), encouraging students to justify their positions with evidence (Simon, Erduran, \& Osborne, 2006), asking open-ended questions to elicit justifications (Jiménez-Aleixandre \& Pereiro-Munoz, 2005; Simon, Erduran, \& Osborne, 2006), challenging ideas by emphasizing their weaknesses or inconsistencies (Mork, 2005), proposing criteria for the construction and evaluation of arguments in the form of prompts (Osborne, Erduran, \& Simon, 2004) or written rubric (Sandoval \& Reiser, 2004; Sampson \& Clark, 2008), revealing epistemic goals in the contributions they made (Simon, Erduran, \& Osborne, 2006), encouraging students' reflection on the changes in their own views as a result of argumentation and on the reasons associated with these changes (Jiménez-Aleixandre, 2008). As regards the development of teaching strategies, the research evidence shows that professional development opportunities can support teachers in their successful enactment of instructional strategies aiming towards a specific learning goal in their classrooms (Jeanpierre, Oberhauser, \& Freeman, 2005). This research has provided a vision of how instructional strategies for argumentation can take place in science classrooms. Yet, a comprehensive framework that also covers meta-strategic or high-level pedagogical strategies supporting or leveraging the quality of argumentation has not been provided. Therefore, building on the prior research, in this study, we conducted a more detailed and comprehensive investigation of these instructional strategies. 


\section{METHODOLOGY}

This section presents the participants, briefly sets the context for research and then elaborates on research design.

\section{Participants}

Participants of this research were one elementary science teacher, two chemistry teachers, and four graduate students. Two of the teachers were teaching at private schools whereas the other was teaching at a private education institution. At the time of the research, teachers had professional experiences ranging from 4 to 11 years. Three participants were pursuing Master's degrees in science education whereas 4 of them were pursuing a $\mathrm{PhD}$ in science or chemistry education. Only one participant, Mesut, had prior knowledge in argumentation as he wrote his master's dissertation on this particular topic. They were at the same time graduate students in science education. Thus, one can assume that the group would be above the level of a randomly selected group of science teachers as they have higher their level of curiosity, enthusiasm for continuous professional development, and motivation in learning and practicing innovative pedagogies. The teachers were equipped with the theoretical background of argumentation in science education and they were experienced in constructing argumentation as they had already participated in argumentation sessions during the graduate course. They have advanced level of understanding argumentation in science education, and thus they are expected to employ more strategies to promote argumentation than a teacher who has no experience or theoretical knowledge in argumentation. The aim of this research was to explore the instructional strategies that lead to argumentation in science classes; therefore we conducted in-depth observation of teachers' practices. We did not analyse the extent to which teachers incorporate known strategies in their classrooms because the studies investigating the instructional strategies (e.g., Simon, Erduran, \& Osborne (2006), Mork (2005)) did not state which of these strategies are effective and create an improvement in argumentation in science classrooms.

\section{The context of the study}

This study was carried out in a public university in Turkey. There are two academic terms in Turkey: spring term and fall term. The courses of Graduate programs at Faculty of Education are open to those who have at least a bachelor's degree from an education program or a science program. The graduate course, during which this study took place, was also available for inservice teachers. It was an elective course. The aim of the course was to develop science teachers' theory and pedagogy of argumentation. The participant teachers planned 3 
argumentation-based science lessons and implemented two of them in their respective schools. The data of this study is generated through the work done by the teachers during this process.

The schools where the participants practiced their teaching were diverse in terms of the age of the students, the school setting (public-private or elementary school- high school or private exam preparation centre), and the number of students in class. For instance, Birhan implemented her lesson at an elementary school. Seher performed her practices at a private education institution where she was teaching chemistry to high school students. Asya performed her lessons in a high school. The other four participants were not employed as teachers, so they practiced the classes at public elementary schools or private institutions after getting the necessary consent and permission from head of the school. However, the diversity in relation to ethnicity, gender and socio-economic status was not considered in this study. The language of instruction is Turkish at schools and all students were able to speak and understand Turkish very well.

The topics of lessons and details of the classes are presented in Table 1.

Table 1. The details of teaching contexts of the participants

\begin{tabular}{|c|c|c|c|c|c|c|c|c|c|}
\hline \multirow[b]{2}{*}{ Participant } & \multirow[b]{2}{*}{ School } & \multicolumn{3}{|c|}{ 1st lesson } & \multicolumn{3}{|c|}{ 2nd lesson } & \multicolumn{2}{|c|}{ 3rd lesson } \\
\hline & & Time* & Topic & Grade & Time & Topic & Grade & Topic & Grade \\
\hline Ahmet & $\mathrm{PES}^{* *}$ & 38.05 & Heat transfer & $6^{\text {th }}$ & 34.16 & $\begin{array}{c}\text { Sound } \\
\text { transfer }\end{array}$ & $6^{\text {th }}$ & Environment & $7^{\text {th }}$ \\
\hline Hale & PES & 40.52 & $\begin{array}{l}\text { Absorption } \\
\text { of light }\end{array}$ & $7^{\text {th }}$ & 33.50 & $\begin{array}{l}\text { Solar } \\
\text { system }\end{array}$ & $7^{\text {th }}$ & $\begin{array}{l}\text { Cell division } \\
\text { and heredity }\end{array}$ & $8^{\text {th }}$ \\
\hline Birhan & PrES & 53.58 & Water cycle & $5^{\text {th }}$ & 15.02 & $\begin{array}{c}\text { Mass and } \\
\text { weight }\end{array}$ & $6^{\text {th }}$ & $\begin{array}{l}\text { Chemical } \\
\text { reactions }\end{array}$ & $7^{\text {th }}$ \\
\hline Mesut & PES & 37.48 & Velocity & $6^{\text {th }}$ & 42.54 & Force & $6^{\text {th }}$ & $\begin{array}{l}\text { Electric } \\
\text { circuits }\end{array}$ & $6^{\text {th }}$ \\
\hline Asya & PHS & 31.02 & $\begin{array}{l}\text { Solution of } \\
\text { gases }\end{array}$ & $10^{\text {th }}$ & 29.34 & $\begin{array}{l}\text { Solubility } \\
\text { of gases }\end{array}$ & $10^{\text {th }}$ & $\begin{array}{l}\text { The effect of } \\
\text { concentration } \\
\text { on solubility }\end{array}$ & $11^{\text {th }}$ \\
\hline Seher & EPC & 39.34 & $\begin{array}{l}\text { Rate of } \\
\text { chemical } \\
\text { reactions }\end{array}$ & $11^{\text {th }}$ & 32.07 & $\begin{array}{c}\text { Equilibrium } \\
\text { in chemical } \\
\text { reactions }\end{array}$ & $11^{\text {th }}$ & Radioactivity & $11^{\text {th }}$ \\
\hline Mahmut & EPC & 47.46 & $\begin{array}{c}\text { Modification } \\
\text { mutation }\end{array}$ & $8^{\text {th }}$ & 46.44 & $\begin{array}{l}\text { Particle } \\
\text { nature of } \\
\text { matter }\end{array}$ & $6^{\text {th }}$ & Evolution & $12^{\text {th }}$ \\
\hline
\end{tabular}

* Time shows the duration of the course given by the teacher.

** PES: public elementary school, PrES: private elementary school, PHS: public high school, EPC: private exam preparation centre

During their teaching practices, the participants video- recorded their teaching by a camera. A week after their implementation, they brought these video-records to the graduate course for self-reflection and evaluation. As a part of the graduate course, teachers and 
researchers exchanged views and provided feedback to one another as they were watching the videos.

\section{Research design}

We conducted a qualitative study in order to describe and interpret the meaning of an experience from the researchers' and the participants' perspectives (Creswell, 2013; Merriam, 2002). The approach to the writing of the study was multiple-case study because our purpose was to explore and describe the shift in the participants' views of their teaching practices and their associated learning throughout the graduate course (Creswell, 2013; Merriam, 2002). Data sources included the participants' video-recorded classroom practices, audio-recorded reflections on their classroom practices, semi-structured interviews with the participants, participants' written materials, such as their argumentation based lesson plans, their self-reflection papers, and the worksheets they collected from the students.

Classroom practices and lesson plans were analysed by Interpretive Content Analysis (ICA). ICA was proposed as an alternative to classical content analysis as it offers better quality of coding and assessment of the coding quality (Ahuvia, 2001). In ICA, generated codes are not considered to be isolated parts from the rest of the text; this is because ICA takes context fully into account and it is not restricted by coding rules. ICA was preferred because the analysis

focused on understanding the instructional strategies used by teachers. In other words, the focus was on identifying the interactions of the teachers which resulted in argumentation or its justification rather than the use of language as in discourse analysis. Therefore, as in latent content analysis, meanings were important rather than the structure. Also teachers were not observed in their classrooms so there was no intervention by the researchers to teachers' inclassroom practices. Therefore, content analysis, as an example of unobtrusive research, which studies social behaviour without affecting it (Babbie, 2007) was appropriate for the data analysis.

In this study, ICA was employed in multiple cycles. In the first round, each transcript of teaching practice for each participant was coded. During the analysis, the coding categories were derived from the literature and mainly from the studies of Simon, Erduran, and Osborne (2006) and Mork (2005) as in constant-comparative method. When a different code emerged during analysis, earlier analyses were reviewed. The categories regarding meta-strategic knowledge were derived in comparison with the study of Zohar (2008). After each coding of a transcript, two researchers came together and discussed the reason and validity until they reached an agreement. The coding unit was a chunk of the transcript, which illustrates some kind of teacher move attempting to initiate, sustain, or advance the argumentation during the lesson. In other words, wherever a teacher's oral contribution to discourse reflected an explicit or implicit goal for the achievement of argumentation in the classroom, it was highlighted and coded (An example of an analysis can be found in Appendix A). In order to overcome the difficulties 
associated with the trustworthiness of the data, specifically in conducting ICA, we explicated the theory that guided this study, explained the method for coding, included example scripts to illustrate the coding, openly wrote the codes, provided justification for the codes, and lastly we formed a thick description of our understanding of argumentation.

In the analysis, the presence or the number of a code or category does not imply whether the teaching was effective or not. Besides, making comparisons was difficult between teachers or different courses of the same teacher due to the variety in contexts. Therefore, we were not able to argue that an improvement or any change happened. Rather, the aim was to demonstrate the instructional strategies that the teachers utilized in their teaching to promote argumentation. Nevertheless, as Simon, Erduran, and Osborne (2006), we argued that the presence of a code demonstrates that the teachers were attempting to teach the associated processes to facilitate students' argumentation. For instance, the presence of a code such as 'encouraged counterargument' indicates that the teacher thought that this process is an important one in students' argumentation and should be promoted. In the following section, all codes and categories and how they were derived from the transcripts of teachers' teaching practices as well as lesson plans were provided.

\section{FINDINGS}

This section presents the codes and categories emerged from the analysis of the participants' lesson plans and teaching practices.

Codes and categories for instructional strategies. Three categories of instructional strategies in relation to argumentation came up in this study. These are i) Basic instructional strategies for argumentation (B-ISA), ii) Meta-level instructional strategies for argumentation (ML-ISA), and iii) meta-strategic instructional strategies for argumentation (MS- ISA). We now explain each of these categories and the relevant codes emerging from these three main categories.

1. Basic instructional strategies for argumentation. B-ISA covers the instructional strategies that are apparent in the participants' teaching practices and lesson plans for initiating or promoting argumentation. The codes emerged in this category were compared with the ones in the studies of Simon, Erduran, and Osborne (2006) and Mork (2005), and they were grouped in the same or similar categories (Table 2). However, the codes and categories constructed in this study are more refined to represent certain nuances between basic ISA and meta-level ISA. This code includes ten strategies employed by teachers to help students develop and construct their argumentation. These strategies are explained in detail with drawing examples from teaching practices. 
Table 2. Codes and categories for basic instructional strategies used by the participants

\begin{tabular}{|c|c|c|}
\hline $\begin{array}{l}\text { Categories- } \\
\text { argumentation } \\
\text { process }\end{array}$ & $\begin{array}{c}\text { Instructional strategies } \\
\text { derived from the literature }\end{array}$ & $\begin{array}{l}\text { Instructional strategies used by the } \\
\text { participants in this study }\end{array}$ \\
\hline $\begin{array}{l}\text { Challenge the } \\
\text { correctness }\end{array}$ & $\begin{array}{c}\text { Rephrase and address question } \\
\text { to other group } \\
\text { Asks for elaboration }\end{array}$ & $\begin{array}{c}\text { Asking for further arguments } \\
\text { Clarification of an argument/ claim(s) by } \\
\text { questioning and/or rephrasing } \\
\text { Clarification of counter positions for further } \\
\text { argumentation by questioning and/or rephrasing } \\
\text { Clarification of justification/ a rebuttal by } \\
\text { questioning and rephrasing }\end{array}$ \\
\hline $\begin{array}{l}\text { Constructing } \\
\text { arguments }\end{array}$ & $\begin{array}{c}\text { Uses writing frame or written } \\
\text { work/prepares } \\
\text { presentations/gives roles }\end{array}$ & $\begin{array}{c}\text { Constructing a problem/ a case for argumentation } \\
\text { Drawing a writing framework to construct an } \\
\text { argument } \\
\text { Providing instructions for an activity } \\
\text { The role of the students }\end{array}$ \\
\hline $\begin{array}{l}\text { Counter arguing/ } \\
\text { debating }\end{array}$ & $\begin{array}{c}\text { Encourages debate } \\
\text { Encourages anticipating } \\
\text { counter-argument }\end{array}$ & $\begin{array}{l}\text { Questioning for further arguments/ claims } \\
\text { Questioning to elicit arguments } \\
\text { Initiating argumentation } \\
\text { Encouraging counter arguments }\end{array}$ \\
\hline $\begin{array}{l}\text { Evaluating } \\
\text { arguments }\end{array}$ & Process - using evidence & $\begin{array}{c}\text { Encouraging the use of } \\
\text { data/observation/information as evidence }\end{array}$ \\
\hline $\begin{array}{l}\text { Extending range of } \\
\text { topic }\end{array}$ & Asks for elaboration & Expanding a claim \\
\hline $\begin{array}{l}\text { Involve more } \\
\text { students }\end{array}$ & $\begin{array}{l}\text { Address question to individual } \\
\text { or group }\end{array}$ & Asking for an argument \\
\hline $\begin{array}{l}\text { Justifying with } \\
\text { evidence }\end{array}$ & $\begin{array}{c}\text { Checks evidence } \\
\text { Prompts justification } \\
\text { Plays devil's advocate }\end{array}$ & $\begin{array}{c}\text { Appealing to evidence } \\
\text { Asking for justification } \\
\text { Playing devil's advocate } \\
\text { Proposing (a) claim(s)/ counter-claim/ alternative } \\
\text { claim(s) } \\
\text { Proposing a counter-argument/ alternative } \\
\text { arguments } \\
\text { Proposing an alternative justification/ a counter- } \\
\text { evidence/ a rebuttal } \\
\text { Providing evidence as experimental data/ figures/ } \\
\text { pictures/graphs/ scientific information/ } \\
\text { statements }\end{array}$ \\
\hline
\end{tabular}


Table 2. (cont'd) Codes and categories for basic instructional strategies used by the participants

\begin{tabular}{|c|c|c|}
\hline $\begin{array}{l}\text { Categories- } \\
\text { argumentation } \\
\text { process }\end{array}$ & $\begin{array}{c}\text { Instructional strategies } \\
\text { derived from the literature }\end{array}$ & $\begin{array}{l}\text { Instructional strategies used by the } \\
\text { participants in this study }\end{array}$ \\
\hline Positioning & Values different positions & $\begin{array}{l}\text { Drawing attention to position/ counter position/ } \\
\text { dilemma } \\
\text { Guiding students to alternative arguments } \\
\text { Encouraging the consideration of } \\
\text { alternative/opposite ideas }\end{array}$ \\
\hline & Encourages ideas & Encouraging more arguments \\
\hline $\begin{array}{l}\text { Reflecting on } \\
\text { argument process }\end{array}$ & Asks about mind-change & Asking for mind-change \\
\hline $\begin{array}{l}\text { Talking and } \\
\text { listening }\end{array}$ & $\begin{array}{l}\text { Encourages discussion } \\
\text { Encourages listening }\end{array}$ & $\begin{array}{l}\text { Encouraging argumentation } \\
\text { Encouraging listening } \\
\text { The role of the teacher }\end{array}$ \\
\hline
\end{tabular}

a. Challenge the accuracy. Mork (2005) developed a typology of teacher interventions where she focused on teachers' role in relation to the management and teacher interventions in argumentation activities. She identified six main factors prompting teacher interventions and some sort of teacher actions that each reason prompts. For example, the accuracy of content due to the misuse of concepts or wrong combination of information might be a reason for a teacher to challenge the accuracy of information by rephrasing and addressing question to other groups or by asking for elaboration.

Similarly, in this study, the teachers asked for further arguments and attempted to clarify argument or the components of argument, such as claim, counter positions, justification or rebuttal by questioning and rephrasing. For example, Asya, in her second lesson, asked students to choose among three coke bottles (one taken right out of fridge and not opened, second sits in the room temperature for 2 days and not opened, and third sits in the room temperature for 5 days but it is opened) based on their understanding of solubility of gases. At some point, she realized that the students' arguments did not go any further and the groups' combination of evidence cards was not correct. Therefore, Asya rephrased and addressed question to other groups in order to create an opportunity for challenging the accuracy:

Teacher: Why do you choose $3^{\text {rd }}$ option when you compare $2^{\text {nd }}$ and $3^{\text {rd }}$ ? Both sit in the same room, so their temperature is the same.

Student: $\quad$ No, we chose both of them.

Teacher: $\quad$ You chose both?

Student: Yes.

Teacher: $\quad$ Ok, I understand. Well, is there anyone who sees the difference between 2nd and 3rd?

b. Constructing arguments. Teachers use writing frameworks or written work, prepare presentations, or give roles as a way to ask students to construct their arguments on a worksheet, 
or to construct arguments that commensurate with their roles in a role play (Simon, Erduran, \& Osborne, 2006).

In this study, the teachers encouraged students to construct arguments in a variety of ways. They constructed a problem or a case for argumentation, developed a writing framework to construct an argument, provided instructions for an activity in order to promote construction of arguments, or described the role of students in constructing an argumentation in their lesson plans. For instance, Ahmet provided students with a figure in his first lesson plan and promoted students' own construction of arguments regarding the heat transfer. The students were asked to make a decision regarding which floor of an apartment would be suitable to live in winter. He also prepared a writing framework to guide students in constructing arguments (Figure 1).

OUR IDEA is;

In apartment ..., on the floor ..., we could live warmer with less gas consumption, because...

The evidence cards that support our idea are the ones with number... because...

We do not agree with the other ideas because...

Figure 1. The writing framework used by one of the teachers to encourage students' constructing arguments

c. Counter arguing/debating. The teachers encouraged counter arguing and debating by questioning for further arguments/ claims, eliciting arguments, initiating argumentation or encouraging students to anticipate counter arguments. For example, Mahmut, in his first lesson encouraged debate by directing questions for further argumentation;

Student: I want to talk about speed in relation to your question. The definition of speed might be, according to what you said, in a definite...

Teacher: $\quad$ Time interval?

Student: $\quad$ Time interval, travelling on a certain road as fast as possible, how to say, with the highest speed or something.

Teacher: Then, according to the explanation our friend just made, who wins the race if car A, B and C keep their speed constant, in the fourth part?

d. Evaluating arguments. Evidence component of argumentation is used to evaluate the process. For example, Seher clarified her goal regarding the use of data/observation/information as evidence in her second lesson. During an argumentation activity on the chemical reactions, she encouraged students to use the graphs provided in a worksheet to support their arguments.

Student1: I will make another explanation. Now the concentration will increase, it will be stronger and it would take more heat.

Student2: The third graph. 
Teacher: $\quad$ OK, we need to make an explanation based on graphs, this is the first one.

e. Extending the range of topics. Mork (2005) indicated that during argumentation, teachers may realize that too few sub-topics are covered or there is incomplete information. In such cases, they need to extend the range of topics by pursuing parts of students' utterances, asking for elaboration, reintroducing or introducing sub-topics. Likewise, the teachers in this study extended the range of topics by expanding a claim. For example, in her first teaching practice, Birhan expanded a claim on the topic of condensation proposed by students;

Student: $\quad$ Teacher, the water will evaporate and then water vapour will stick to the stretch film. There, it will form a cloud. [CLAIM 1]

Teacher: Then, you expect rain. [CLAIM 1 EXPANDED]

Student: Then, there will be rain. [CLAIM1.2]

f. Involve more students. In some cases, very few students may be involved in argumentation. Teachers may address the question to another student or a group in order to involve more students into argumentation (Mork, 2005). For example, in his second teaching practice, Mahmut asked the other groups' opinions regarding the competing theories he provided;

Student: We don't agree with sentence 1 because

Teacher: $\quad$ Yes, the one you agree is important for me.

Student: Then, we don't agree with any of the sentences. [CLAIM]

Teacher: You don't agree with any of them. [REPHRASING] What other groups think of this?

g. Justifying with evidence. Simon, Erduran, and Osborne (2006) indicated that teachers often attempted to enhance the process of justification. For example, appealing to evidence code in this typology refers to the dialogue when teachers question the validity or relevance of the evidence that the students used. For instance, Ahmet, in his first teaching practice, asked students to use evidence cards to support their arguments. The topic of argumentation was the transfer of heat. He provided the students with an activity, which required them to use their knowledge on the transfer of heat to decide which floor $\left(1^{\text {st }}, 2^{\text {nd }}\right.$ or $\left.3^{\text {rd }}\right)$ of the given three apartments (Apartment A, B, and C) would be most suitable to live in winter. In the following script, Ahmet questioned the evidences of the students to check whether they have a base:

Teacher: $\quad 7,8$ and 10 (referring to evidence cards). How do these support your arguments? [QUESTIONING]

Student: We thought convection would be more useful for us. Here it generally mentions convection. For example, heat goes from the warm to the cold matter. In the convection, warm air and cold air takes each other's place 
and the heat may be transferred from hot weather to cold weather. [ARGUMENT]

Teacher: How is it related to the apartment example? [QUESTIONING]

Student: Because there is convection in the apartment. Eight says that sun gives heat by radiation. Sun gives heat by radiation here too. Ten says warm air rises up. This is convection, so it supports. [ARGUMENT]

Teacher: Well, for A-2 you say supported by ten. When we look at the shape of the apartment, where is the warmed air? [QUESTIONING]

Student: $\quad$ Here (shows by finger)

To encourage argumentation, all teachers tended to provide experimental data/ figures/ pictures/ graphs/ scientific information/ statements in their lesson plans and teaching practices. Teachers also prompted justification when they wanted students to provide justification for their claims. As Simon, Erduran and Osborne (2006) argued that these prompts are often in the form of probes such as "why?" or "how do you know?" To illustrate, an example from Mahmut's teaching practice is provided. Mahmut provided statements to evoke thinking;

Teacher: $\quad$ What does student A say?

Student: $\quad$ A says that if a man has a big body, his offspring have a big body, too.

Student: It is somehow correct. [CLAIM]

Teacher: How is it?

Student: $\quad$ For example, if my parents are tall, there is $95 \%$ chance of my being tall. [WARRANT]

Teachers also played devil's advocate to stimulate further justification of arguments in several ways. For example, they proposed (a) claim(s)/ counter-claim/ alternative claim(s); a counter-argument/ alternative arguments; or an alternative justification/ counter-evidence/ a rebuttal.

h. Positioning. There may be different positions on a subject that might lead one to evaluate his/her claims in consideration of multiple views. Therefore, teachers would need to encourage alternative ideas so that students could recognize that there were choices (Simon, Erduran, \& Osborne, 2006).

In this study, the teachers demonstrated that they value different positions in their actions such as drawing attention to position/ counter position/ dilemma, guiding students to alternative arguments, and encouraging the consideration of alternative/opposite ideas. For example, in her second teaching practice, Asya encouraged students to consider alternative positions;

Teacher: Which evidence cards did you use?

Student: $\quad$ As the temperature increases, the movement and speed of water molecules increase. This makes harder to keep gas molecules inside. [JUSTIFICATION] 
Teacher: Well, did you use this one only? (yes) Did you use the second one? (no) Why not?

i. Reflecting on argument process. Simon, Erduran, and Osborne (2006) indicated that teachers gave importance to encourage students to reflect on the process of argumentation by asking them if they experienced any change of ideas as a result of argumentation. The implicit message is that it is legitimate to change ideas or positions if you decide that an opposing argument is stronger. For instance, Mahmut asked students if they changed their mind about the concepts of element and molecule;

Student: In our group, the part after 'because' was not appropriate, so we changed that.

Teacher: What did you change?

Student: In the $4^{\text {th }}$ item, we changed the part after 'because'.

Teacher: What was your answer and how did you change it?

Student: Initially, we came to a conclusion that the atoms composing the methane molecule are different. However, now we say that atoms are in different sizes.

j. Talking and listening. Argumentation is only possible when students are able to work in groups, listening to each other and articulating their own ideas (Simon, Erduran, \& Osborne, 2006). Therefore, teachers need to familiarize students to working discursively in groups and encourage listening. Hale, for example, reminded students to listen to each other several times;

Teacher: Ok, we are listening to the first group. Let's see what they think. It is a very interesting question. I guess there will be interesting answers. Everybody, please listen to your friend.

The teachers encouraged discussion, and specifically argumentation in students' interaction. For instance, Ahmet, in his first lesson encouraged argumentation among students by asking them to listen to each other so that they can articulate their own ideas;

Teacher: Well, in the remaining time, let's evaluate the groups. For example, what do the groups who do not agree with other groups say about their ideas? For example, $2^{\text {nd }}$ group chose B-2, and $1^{\text {st }}$ group chose A-2. What does the group who chose A-2 say about the items told by the other group who chose B-2?

2. Meta-level instructional strategies for argumentation. ML-ISA covers the instructional strategies in the participants' teaching practices and lesson plans for argumentation but requires higher-order thinking. In other words, teachers need to think and plan implementing these strategies. For example, "evaluating arguments" is an instructional strategy that was generated in 
the process of teachers' evaluation of the use of evidence in argumentation. However, this study draws attention to the fact that "evaluating arguments" can be an instructional strategy that could be generated in the category of B-ISA and also of ML-ISA. In other words, teachers may evaluate the use of evidence as a general argumentative practice as the argumentation proceeds or they may demonstrate an intentional planning and acting to evaluate the use of evidence depending on the context. Thus, the codes and categories corresponding to the ones by Simon, Erduran, and Osborne (2006) and Mork (2005) were refined in a number of different ways considering the nuances in teachers' practices (Table 3).

Table 3. Codes and categories for meta-level instructional strategies used by the participants

\begin{tabular}{|c|c|c|}
\hline $\begin{array}{l}\text { Categories of } \\
\text { argumentation processes }\end{array}$ & $\begin{array}{l}\text { Instructional strategies } \\
\text { derived from the literature }\end{array}$ & $\begin{array}{l}\text { Instructional strategies used by the } \\
\text { participants in this study }\end{array}$ \\
\hline \multirow[t]{5}{*}{ Evaluating arguments } & Evaluates arguments & Developing a rubric as assessment criteria \\
\hline & & $\begin{array}{c}\text { Developing an assessment strategy for an } \\
\text { argumentation lesson }\end{array}$ \\
\hline & & $\begin{array}{c}\text { Drawing an evaluation framework for } \\
\text { justification }\end{array}$ \\
\hline & Setting expectations & $\begin{array}{l}\text { Setting expectations for students' learning } \\
\text { about argumentation }\end{array}$ \\
\hline & & $\begin{array}{l}\text { Setting expectations for the quality of } \\
\text { argumentation }\end{array}$ \\
\hline Focus on debate technique & Drawing rules & $\begin{array}{l}\text { Drawing rules for a teaching } \\
\text { method/strategy }\end{array}$ \\
\hline \multirow[t]{3}{*}{$\begin{array}{l}\text { Knowing meaning of } \\
\text { argument }\end{array}$} & $\begin{array}{l}\text { Choosing/naming a specific } \\
\text { strategy }\end{array}$ & $\begin{array}{c}\text { Choosing a specific strategy to implement } \\
\text { argumentation }\end{array}$ \\
\hline & & $\begin{array}{c}\text { Naming a specific strategy to implement } \\
\text { argumentation }\end{array}$ \\
\hline & $\begin{array}{l}\text { Identifying objectives/ } \\
\text { purpose }\end{array}$ & Defining the objectives of a specific strategy \\
\hline
\end{tabular}

The researchers can differentiate whether an act is a meta-level or it is not in context. This decision requires teachers' prior knowledge and strategies regarding argumentation as well as the common teaching practices. For example, a teacher's move such as stating explicitly the objectives of the lesson might be a regular practice. In such a case, this act could not be evaluated as a meta-level instructional strategy. However, in contrast to the regular teaching practices, if teacher intentionally plans and calls the objectives in the classroom for that specific class, then this act is considered as a meta-level action. Now, we present three codes to illustrate ML-ISA.

a. Evaluating arguments. Simon, Erduran, and Osborne (2006) categorized teacher utterances as evaluating arguments "when teachers had clear goals focusing on the evaluation of arguments and when they asked students to make judgements about exemplary arguments. In 
doing so, they either emphasized that having evidence is important or they focused on the nature of the evidence." (p.251). In this study, the category was extended to include teachers' instructional practices that clearly target the objectives of the lesson such as developing a rubric as assessment criteria, developing an assessment strategy for an argumentation lesson, or drawing an evaluation framework for justification.

For example, in her third lesson plan, Asya set clear goals regarding the evaluation of students' argumentation. She adapted an assessment strategy to evaluate students' posters:

"Remember, as you critique the work of others, you have to decide if their conclusions are valid or acceptable based on the quality of their explanation and how well they are able to support their ideas. In other words, you need to determine whether their arguments are persuasive and convincing. To do this, ask yourself following questions and write down your answers:

1) Is their explanation sufficient (does it explain everything it needs to) and coherent (does it have any contradictions)?

2) Are their variables correct?

3) Did they use genuine evidence (did they organize their data in a way that it shows a trend over time, a relationship between variables, or a difference between groups) and did they use enough evidence to support their ideas (did they use than one piece of evidence and were all their ideas supported by evidence)?

4) Is their evidence of high quality? In other words, is their evidence valid (did they use appropriate methods to gather the data) and reliable (did they attempt to reduce error in their measurements or observations)?

5) Is there any counterevidence that does not support their explanation?

6) How well does their explanation fit with other theories and laws that are used in science to explain or describe how the world works?

7) Is their reasoning adequate (did they explain why the evidence was used and why it supports the explanation) and appropriate (rational and sound)?"

Teachers may have different standards in their minds to assess quality of students' argumentation or students' learning during argumentation. In this study, these standards were evident in their lesson plans and these were coded as setting expectations.

b. Focusing on debate technique. Turn-taking in debates is a significant task that teachers need to manage as students may not be used to the debate techniques. In this study, the teachers drew rules for teaching method argumentation or an associated strategy to familiarize students 
with the argumentation skills. For example, in his first argumentation teaching practice, Mahmut set rules regarding the argumentation process as follows;

Teacher: There is no superior answer here; everyone has his/her own opinion. Everyone will defend their own ideas. In your groups, we talked about your personal opinions on the issue. Now, I will distribute clue cards to you. ... When everyone is ready to talk about his/her own opinion on the clue card, you will choose a spokesman to tell us your idea in your group.

c. Knowing meaning of argument. Simon, Erduran, and Osborne (2006) indicated that teachers may make attempts to support students' understanding of what argument means. In this study, teachers' ISA in relation to knowing meaning of argument was also considered to be a meta-level knowledge of argumentation. For example, choosing and/or naming a specific strategy in relation to argumentation, or identifying objectives and/or purpose in relation to argumentation in their teaching practices or lesson plans require teachers' knowledge of argumentation as a way of learning science. Therefore, these attempts were coded as meta-level instructional strategy for argumentation. For instance, Mahmut explicitly called a specific strategy to implement argumentation in his first teaching practice;

Teacher: We call this concept cartoon, which is a strategy used for science education. It asks that whether there is any effect of physical training on the offspring.

3. Meta-strategic instructional strategies for argumentation. Zohar (2008) defines metastrategic knowledge as "general knowledge about the cognitive procedures that are being manipulated. It consists of following abilities: making generalizations and drawing rules regarding a thinking strategy; naming the thinking strategy; explaining when, why and how such a thinking strategy should be used, when it should not be used; what are the disadvantages of not using appropriate strategies, and what task characteristics call for the use of the strategy. (Zohar, 2008, p. 254).

In this study, cognitive procedures that are closely related to argumentation were identified as constructing arguments, coordinating evidence, backing a claim, and providing justification (Table 4), all of which refer to the research of Zohar (2006; 2008; 2012). Three codes of meta-strategic instructional strategies for argumentation are presented below:

Table 4. Codes and categories for meta-strategic instructional strategies used by the participants

\begin{tabular}{lc}
\hline $\begin{array}{l}\text { Categories of argumentation processes as reflected in } \\
\text { teachers' contributions }\end{array}$ & $\begin{array}{c}\text { Instructional strategies used by } \\
\text { participants in this study }\end{array}$ \\
\hline Drawing rules for a thinking strategy & Constructing arguments \\
Modelling the thinking strategy & Constructing arguments \\
& Coordinating evidence \\
& Providing justification \\
\hline
\end{tabular}


a. Drawing rules for a thinking strategy. Zohar (2006) indicated that specific thinking strategies can be fostered in a specific lesson by means of purposefully designed learning activities. In this study, the teachers purposefully designed argumentation activities, and in some occasions, they explained students the general elements of this thinking activity. For example, in his second lesson, Mahmut addressed a specific thinking pattern to construct arguments repeatedly so that students could formulate the generalizations and rules;

Teacher: Did you have a discussion? What was your discussion based on? Did you have a disagreement?

Student: $\quad$ Do you mean different point of views?

Teacher: Yes. Did you have any different viewpoints?

Student: We agreed on the answers.

Student: We had different ideas but we agreed on

Teacher: What were they?

Student: $\quad$ For example, I think that the molecule is composed of two types of atoms. My friend, on the other hand, thinks that the molecule is composed of more than one type of atom. I mean, he thinks that there are not only two types of atoms but more.

Teacher: Do you mean that there are three types of atoms? Well, how did you convince your friend?

Student: I said, the purple atoms are one type and the yellow atom is a different type.

Teacher: So, you said that there are two types of atoms, not more than two. You used their colour as evidence.

b. Modelling thinking strategy. Zohar (2006) proposed that teachers' meta-strategic knowledge may lead them to develop effective pedagogical tools for teaching higher order thinking. In this study, the teaching practices of some teachers reflect such modelling of higher order thinking skills such as constructing arguments, coordinating evidence, and providing justification.

For example, Mesut, in his first argumentation lesson, modelled constructing arguments;

Teacher: Here, in the second part, there are three friends, statements and some claims related to the observations of the three buddies who went to race. You will try to show whether claims are right or wrong? If it is right, why is it right? If it is wrong, why is it wrong?" ...Hasan, for example, agrees with Can's claim. He will say that "I agree with Can's claim because of 
this or that" or "this also supports my claim because....". First, we will do this in groups and then we will discuss altogether.

c. Naming the thinking strategy. In teaching of higher order thinking skills, such as constructing arguments, coordinating evidence and providing justification, teachers should demonstrate the knowledge of the thinking strategies explicitly during teaching. They should also be able to explain when, why, and how to use these thinking strategies in the process of argumentation and problem solving (Zohar, 2006). In this study, there were cases where the teachers name the thinking strategies either in their lesson plans or teaching practices.

For instance, Mesut wrote following thinking strategies that he aimed to foster in his lesson;

"All lessons are argumentation based. Therefore, the design of the lessons contain critical thinking processes such as generating arguments, counter arguments, rebuttals, justifications and etc. regarding given knowledge claims."

So far, we have presented the categories and codes emerged from our analysis and explained how each of them contributed to developing argumentation skills of students. In the next section, we further scrutinise what these findings tell us about argumentation in science education and make suggestions for further research.

\section{DISCUSSION AND CONCLUSION}

This study builds on argumentation in science education research by focusing on the instructional strategies for initiating and sustaining argumentation in science classrooms. The instructional strategies derived from the teachers' classroom practices and lesson plans were diverse. For example, there were strategies already listed in science education literature to promote argumentation. Some of these strategies aim to assess whether students integrate empirical evidence to support their claims (McNeill \& Pimentel, 2010); to encourage students to elaborate their arguments by means of employing more evidences and considering alternative viewpoints (Simon, Erduran, \& Osborne, 2006); to design argumentative learning tasks by using specific instructional strategies, such as constructing open-ended, ill-structured cases or questions that fosters the multiple viewpoints (Berland \& Hammer, 2012; Berland \& McNeill, 2010; Berland \& Reiser, 2009); to set a classroom environment where students listen to their peers, argue and question ideas in a persuasive discourse (McNeill \& Knight, 2013), and to model argumentation when the students had difficulty to justify their claims by providing arguments or counter-arguments (McNeill, 2009).

The teachers in this research, on the other hand, developed a meta-level understanding of argumentation through a graduate course, which was supported with meta-level discussions with experts and other graduate students. Therefore, they used and developed instructional strategies referred as meta-level or meta-strategic, which are significant in teaching how to think. For example, teachers modelled how to construct arguments and counterarguments and to provide 
evidence. They discussed the general characteristics of sound argumentation, such as the components of an argument, the nature of evidence, when, why, and how to coordinate evidence and provide justification. These strategies are important to provide students with an awareness of the meta-level knowledge pertaining to the role of argumentation in constructing scientific knowledge (Zohar, 2008).

This research also provided a detailed coding framework to explore science teachers' instructional practices as they implemented argumentation based lessons. The coding framework may guide further research to understand the elements of argumentation that the teachers have difficulty in integrating to their teaching and in promoting students' argumentation. Furthermore, the instructional strategies coded in teachers' practice may be helpful for researchers to identify the skills or competencies prioritized by teachers during argumentation. This might also be helpful for professional developers or teacher educators in the process of designing content of a professional development course/programme. For example, teachers may not emphasize alternative ideas in students' argumentation because they may have difficulty in managing different viewpoints, or they may have a positivistic approach to scientific knowledge, which assumes the existence of a truth. They may simply be ignorant of the multiple viewpoints and focus on the expected responses. This can be drawn from the data generated through the coding of teachers' instruction. In such a case, the professional developers might assist teachers developing these aspects of the argumentation.

Over all, this study has several limitations. First our participants were limited with only seven science teachers and these teachers were unique in terms of their demographic characteristics. They were graduate students, and they have a background in different disciplines of science. Therefore, the researchers may wonder whether these instructional strategies could be applicable in other settings. We explicated the characteristics of the group as well as the research process in detail so that the readers may have an idea how comparable these teachers with other cases. Further research can conduct this study with different teacher groups to find out if similar or different patterns of instructional strategies will come up. Second limitation is that regardless of the variety or the large number of data sources, it is difficult to understand teachers' intention in carrying out a particular action during the coding. Therefore, we suggest that the researchers can conduct further interviews with teachers to clarify the aims of their action. In this research, we did not attempt to explore students' argumentation or their experiences regarding argumentation in response to teachers' instructional practices. Therefore, further research can look into the effects of the instructional strategies on students' outcomes.

To conclude, this study contributes to an understanding of in-service science teachers' facilitation of argumentation practices, particularly through the use of instructional strategies, identified as basic instructional strategies for argumentation, meta-level instructional strategies for argumentation, and meta-strategic instructional strategies for argumentation.

\section{REFERENCES}


Bell, P., \& Linn, M. C. (2000). Scientific arguments as learning artifacts: Designing for learning from the web with KIE. International Journal of Science Education, 22(8), 797-817.

Berland, L. K., \& Hammer, D. (2012). Framing for scientific argumentation. Journal of Research in Science Teaching, 49(1), 68-94.

Berland, L. K., \& McNeill, K. L. (2010). A learning progression for scientific argumentation: Understanding student work and designing supportive instructional contexts. Science Education, 94, 765-793.

Berland, L. K., \& Reiser, B. J. (2009). Making sense of argumentation and explanation. Science Education, 93, 26-55.

Bybee, R. W. (2011). Scientific and engineering practices in K-12 classrooms: Understanding "A framework for K-12 science education”. Science and Children, 49(4), 10-16.

Clark, D. B., \& Sampson, V. D. (2007). Personally-seeded discussions to scaffold online argumentation. International Journal of Science Education, 29(3), 253-277.

Commission, E., EACEA, Eurydice. (2012). Developing Key Competences at School in Europe: Challenges and Opportunities for Policy - 2011/12 (pp. 1-72).

Creswell, J. W. (2013). Qualitative inquiry and research design: Choosing among five approaches. California: SAGE publications.

Davis, E. A., \& Krajcik, J. S. (2005). Designing educative curriculum materials to promote teacher learning. Educational Researcher, 34(3), 3-14.

Dawson, V. M., \& Venville, G. (2010). Teaching strategies for developing students' argumentation skills about socioscientific issuesin high school genetics. Research in Science Education, 40, 133-148.

Driver, R., Newton, P., \& Osborne, J. (2000). Establishing the norms of scientific argumentation in classrooms. Science Education, 84, 287-312.

Duschl, R. A., Ellenbogen, K., \& Erduran, S. (1999). Promoting argumentation in middle school science classrooms: A project SEPIA evaluation. Paper presented at the Annual Meeting of the National Association for Research in Science Teaching, (pp. 1-18). Boston, MA.

Duschl, R. A., \& Osborne, J. (2002). Supporting and promoting argumentation discourse in science education. Studies in Science Education, 38(1), 39-72.

Duschl, R. A. (2008). Quality argumentation and epistemic criteria. In S. Erduran, \& M. P. Jiménez-Aleixandre (Eds.), Argumentation in science education: Perspectives from classroom-based research (pp. 159-175). Dordrecht: Springer.

Erduran, S., \& Jimenez-Aleixandre, M. P. (2012). Argumentation in Science Education Research: Perspectives from Europe. In D. Jorde \& J. Dillon (Eds.) Science Education Research and Practice in Europe: Retrospective and Prospective (pp. 253-289). Rotterdam, The Netherlands: Sense Publishers. 
Erduran, S., Ozdem, Y., \& Park, J. Y. (2015). Research trends on argumentation in science education: a journal content analysis from 1998-2014. International Journal of STEM Education, 2(1), 1-12.

Evagorou, M., \& Dillon, J. (2011). Argumentation in the teaching of science. In D. Corrigan, J. Dillon, \& R.Gunstone (Eds.), The professional knowledge base of science teaching (pp. 189-204). New York: Springer.

Garcia-Mila, M., \& Andersen, C. (2008). Cognitive foundations of learning argumentation. In S. Erduran, \& M. P. Jiménez-Aleixandre (Eds.), Argumentation in science education: Perspectives from classroom-based research (pp. 29-46). Dordrecht: Springer.

Jeanpierre, B., Oberhauser, K., \& Freeman, C. (2005). Characteristics of professional development that effect change in secondary science teachers' classroom practices. Journal of Research in Science Teaching, 42(6), 668-690.

Jiménez-Aleixandre, M. P. (2008). Designing argumentation learning environments. In S. Erduran, \& M. P. Jiménez-Aleixandre (Eds.), Argumentation in science education: Perspectives from classroom-based research (pp. 91-115). Dordrecht: Springer.

Jiménez-Aleixandre, M. P., \& Erduran, S. (2008). Argumentation in science education: An overview. In S. Erduran, \& M. P. Jiménez-Aleixandre (Eds.), Argumentation in science education: Perspectives from classroom-based research (pp. 3-27). Dordrecht: Springer.

Jiménez-Aleixandre, M. P., \& Pereiro-Munoz, C. (2005). Argument construction and change while working on a real environment problem. In K. Boersma, M. Goedhart, O. De Jong, \& H. Eijkelhof (Eds.), Research and the quality of science education (pp. 419-431). Netherlands: Springer.

Kim, H., \& Song, J. (2006). The features of peer argumentation in middle school students' scientific inquiry. Research in Science Education, 36, 211-233.

Knight-Bardsley, A. \& McNeill, K. L. (2016). Teachers' pedagogical design capacity for scientific argumentation. Science Education, Early View, DOI: 10.1002/sce.21222.

Kolsto, S. D., \& Ratcliffe, M. (2008). Social aspects of argumentation. In S. Erduran, \& M. P. Jiménez-Aleixandre (Eds.), Argumentation in science education: Perspectives from classroom-based research (pp. 116-136). Dordrecht: Springer.

Kuhn, D. (1993). Science as argument: Implications for teaching and learning scientific thinking. Science Education, 77(3), 319-337.

Kuhn, L., \& Reiser, B. J. (2006). Structuring activities to foster argumentative discourse. American Educational Research Association. San Francisco, CA.

Kuhn, D., \& Udell, W. (2003). The development of argument skills. Child Development, 74(5), $1245-1260$. 
Lee, M. H., Wu, Y. T., \& Tsai, C. C. (2009). Research trends in science education from 2003 to 2007: A content analysis. International Journal of Science Education, 31(15), 19992020.

McNeill, K. L. (2009). Teachers' use of curriculum to support students in writing scientific arguments to explain phenomena. Science Education, 93, 233-268.

McNeill, K. L., González Howard, M., Katsh Singer, R., \& Loper, S. (2016). Pedagogical content knowledge of argumentation: Using classroom contexts to assess high quality PCK rather than pseudoargumentation. Journal of Research in Science Teaching, 53(2), 261-290.

McNeill, K. L., \& Knight, A. M. (2013). Teachers' pedagogical content knowledge of scientific argumentation: The impact of professional development on K-12 teachers. Science Education, 97, 936-972.

McNeill, K. L., \& Krajcik, J. (2008). Scientific explanations: Characterizing and evaluating the effects of teachers' instructional practices on student learning. Journal of Research in Science Teaching, 45(1), 53-78.

McNeill, K. L., \& Pimentel, D. S. (2010). Scientific discourse in three urban classrooms: The role of the teacherin engaging high school students in argumentation. Science Education, 94, 203-229.

Merriam, S. B. (2002). Introduction to qualitative research. In S. B. Merriam (Ed.), Qualitative research in practice: Examples for discussion and analysis (pp. 1-33). San Francisco: Jossey-Bass.

Ministry of National Education in Turkey (MNE) (2013). İlköğretim kurumlarl (ilkokullar ve ortaaokullar) fen bilimleri dersi (3, 4, 5, 6, 7 ve 8. sinıflar) ögretim programı [Elementary (primary and middle school) Science Curriculum (3rd, 4th, 5th, 6th, 7th and 8th grades)]. Ankara: Talim ve Terbiye Kurulu Başkanlığı.

Mork, S. M. (2005). Argumentation in science lessons: Focusing on the teacher's role. Nordic Studies in Science Education, 1(1), 17-30.

National Research Council (NRC) (2012). A framework for k-12 science education: Practices, crosscutting concepts and core ideas. Washington, DC: The National Academies Press.

Newton, P., Driver, R., \& Osborne, J. (1999). The place of argumentation in the pedagogy of school science. International Journal of Science Education, 21(5), 553-576.

Osborne, J. (2005). The role of argument in science education. In K. Boersma, M. Goedhart, O. De Jong, \& H. Eijkelhof (Eds.), Research and the quality of science education (pp. 367380). Netherlands: Springer.

Osborne, J. (2014). Teaching scientific practices: Meeting the challenge of change. Journal of Science Teacher Education, 25, 177-196. 
Osborne, J., Erduran, S., \& Simon, S. (2004). Enhancing the quality of argumentation in school science. Journal of Research in Science Teaching, 41(10), 994-1020.

Patronis, T., Potari, D., \& Spiliotopoulou, V. (1999). Students' argumentation in decisionmaking on a socio-scientific issue: Implications for teaching. International Journal of Science Education, 21(7), 745-754.

Sampson, V., \& Blanchard, M. R. (2012). Science teachers and scientific argumentation: Trends in views and practice. Journal of Research in Science Teaching, 49(9), 1122-1148.

Sampson, V., \& Clark, D. (2008). Assessment of the ways students generate arguments in science education: Current perspectives and recommendations for future directions. Science Education, 92, 447-472.

Sampson, V., Grooms, J., \& Walker, J. (2009). Argument-driven inquiry: A way to promote learning during laboratory activities. The Science Teacher, November, 42-47.

Sandoval, W. A., \& Reiser, B. J. (2004). Explanation-driven inquiry: Integrating conceptual and epistemic scaffolds for scientific inquiry. Science Education, 88, 345-372.

Shulman, L. S. (1986). Those who understand: Knowledge growth in teaching. Educational Researcher, 15(2), 4-14.

Science Teacher Education Advanced Methods (S-TEAM). (2010). Report on argumentation and teacher education in Europe. Trondheim: S-TEAM /NTNU.

Simon, S., Erduran, S., \& Osborne, J. (2006). Learning to teach argumentation: Research and development in the science classroom. International Journal of Science Education, 28(2), 235-260.

Simon, S., \& Johnson, S. (2008). Professional learning portfolios for argumentation in school science. International Journal of Science Education, 30(5), 669-688.

Simon, S., Richardson, K., Howell-Richardson, C., Christodolou, A., \& Osborne, J. (2010). Professional development in the use of discussion and argument in secondary school science departments. International Seminar, Professional Reflections, National Science. York.

Simonneaux, L. (2008). Argumentation in socio-scientific contexts. In S. Erduran, \& M. P. Jiménez-Aleixandre (Eds.), Argumentation in science education: Perspectives from classroom-based research (pp. 179-199). Dordrecht: Springer.

Tümay, H. (2008). Argumentation focused chemistry teaching. Ankara: Unpublished PhD dissertation, Gazi University.

Walker, J. P., \& Sampson, V. (2013). Learning to argue and arguing to learn: Argument-driven inquiry as a way to help undergraduate chemistry students learn how to construct arguments and engage in argumentation during a laboratory course. Journal of Research in Science Teaching, 50(5), 561-596. 
Zohar, A. (2006). The nature and development of teachers' metastrategic knowledge in the context of teaching higher order thinking. Journal of the Learning Sciences, 15(3), 331377.

Zohar, A. (2008). Science teacher education and professional development in argumentation. In S. Erduran, \& M. P. Jiménez-Aleixandre (Eds.), Argumentation in science education: Perspectives from classroom-based research (pp. 245-268). Dordrecht: Springer.

Zohar, A. (2012). Explicit teaching of metastrategic knowledge: Definitions, students' learning, and teachers' professional development. (A. Zohar, \& Y. J. Dori, Eds.) Dordrecht: Springer. 


\section{Appendix A. Examples of data analysis}

Video Record- $1^{\text {st }}$ less -2. wook

00.00.15 (T) now, I want the groups to tell me which clue cards support their ideas. And I want them to explain how these support their ideas. At this point, we need to be careful about each group will listen to the other groups' ideas and then tell us why the idea could not be true. Now, let's start with the first group. Which proposals support you? QUESTIONING

$00.00 .43 \quad$ (S) we thought 7,8 and 10. EVIDENCE

$00.00 .44 \quad$ (T) 7, 8 and 10. How these support you? QUESTIONING

00.00.50 (S) we thought convection would be more useful for us. Here generally, it talks about convection. For example, heat goes from the warm to the cold matter. In the convection warm air and cold air exchanges their place and maybe warm to cold, heat is transferred. In eight ARGUMENT

00.01 .08 (T) how is it related to the apartment example? QUESTIONING

00.01.11 (S) because there is convection in the apartment. Eight says that sun gives heat by radiation. The same thing; sun gives heat by radiation here. Ten says warmed air rises up. This is convection s it supports. ARGUMENT

00.01.26 (T) well, for A-2 you say supported by ten. When we look at the shape of the apartment, where is the warmed air? QUESTIONING

00.01.35 (S) here (shows by finger)

00.01.41 (T) ok. Let's listen to the second group's idea. Thank you.

$00.01 .43 \quad(\mathrm{~S})$ teacher we

00.01.44 (T) you said that apartment B, $2^{\text {nd }}$ floor would be warmer.

00.01.49 (S) our idea eight supports. We only chose eight. As eight, we think there is heating by radiation.

00.02.07 (T) you say by radiation, $2^{\text {nd }}$ floor flat is warmer. What does the third group say?

00.02.13 (S) we thought 8 and 10 because apartment $A$ heats by radiation and becomes warmer when the hot air rises. ARGUMENT

00.02.36 (T) what about at night? QUESTIONING

00.02.37 (S) when it is night, the air has already been warmed up and so it becomes warmer. ARGUMENT

00.02.47 (T) so at night becomes warmer. REPHRASINGWhat does fourth group say?

00.02.49 (S) teacher, we chose 6,8 , and 10 because

00.02.59 (T) you chose 6, 8 and 10. How do these ideas support your idea?
Gsm-

GR-DRAWING RULES TO COORDINATE GROUP DISCUSSION

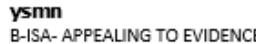

ysmn

REPHRASIFCATION OF AN ARGUMENT BY QUESTIONING AND

REPHRASING

YSmn
B-ISA-APPEALNG TO EVIDENCE

* GPK refers to General Pedagogical Knowledge

Figure a. Teaching practice analysis 

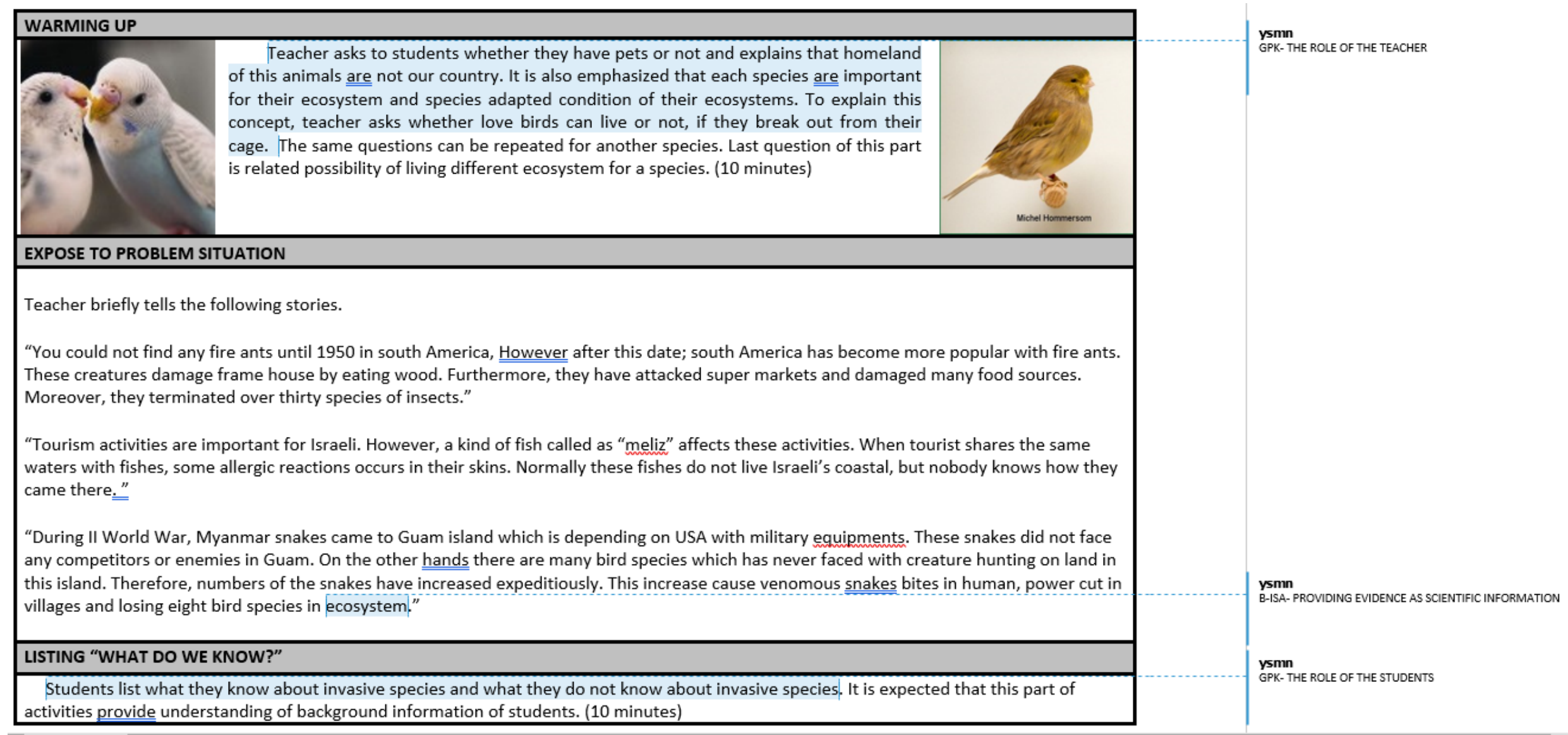

* GPK refers to General Pedagogical Knowledge

Figure b. Lesson plan analysis 
OUR IDEA is;

In apartment ..., on the floor ..., we could live warmer with less gas consumption, because...

The evidence cards that support our idea are the ones with number... because...

We do not agree with the other ideas because...

Figure 1. The writing framework used by one of the teachers to encourage students' constructing arguments 
Table 1. The details of teaching contexts of the participants

\begin{tabular}{|c|c|c|c|c|c|c|c|c|c|}
\hline & & \multicolumn{3}{|c|}{ 1st lesson } & \multicolumn{3}{|c|}{ 2nd lesson } & \multicolumn{2}{|c|}{ 3rd lesson } \\
\hline Participant & School & Time* & Topic & Grade & Time & Topic & Grade & Topic & Grade \\
\hline Ahmet & $\mathrm{PES}^{* *}$ & 38.05 & Heat transfer & $6^{\text {th }}$ & 34.16 & $\begin{array}{l}\text { Sound } \\
\text { transfer }\end{array}$ & $6^{\text {th }}$ & Environment & $7^{\text {th }}$ \\
\hline Hale & PES & 40.52 & $\begin{array}{l}\text { Absorption } \\
\text { of light }\end{array}$ & $7^{\text {th }}$ & 33.50 & $\begin{array}{l}\text { Solar } \\
\text { system }\end{array}$ & $7^{\text {th }}$ & $\begin{array}{l}\text { Cell division } \\
\text { and heredity }\end{array}$ & $8^{\text {th }}$ \\
\hline Birhan & PrES & 53.58 & Water cycle & $5^{\text {th }}$ & 15.02 & $\begin{array}{l}\text { Mass and } \\
\text { weight }\end{array}$ & $6^{\text {th }}$ & $\begin{array}{l}\text { Chemical } \\
\text { reactions }\end{array}$ & $7^{\text {th }}$ \\
\hline Mesut & PES & 37.48 & Velocity & $6^{\text {th }}$ & 42.54 & Force & $6^{\text {th }}$ & $\begin{array}{l}\text { Electric } \\
\text { circuits }\end{array}$ & $6^{\text {th }}$ \\
\hline Asya & PHS & 31.02 & $\begin{array}{l}\text { Solution of } \\
\text { gases }\end{array}$ & $10^{\text {th }}$ & 29.34 & $\begin{array}{l}\text { Solubility } \\
\text { of gases }\end{array}$ & $10^{\text {th }}$ & $\begin{array}{l}\text { The effect of } \\
\text { concentration } \\
\text { on solubility }\end{array}$ & $11^{\text {th }}$ \\
\hline Seher & EPC & 39.34 & $\begin{array}{l}\text { Rate of } \\
\text { chemical } \\
\text { reactions }\end{array}$ & $11^{\text {th }}$ & 32.07 & $\begin{array}{c}\text { Equilibrium } \\
\text { in chemical } \\
\text { reactions }\end{array}$ & $11^{\text {th }}$ & Radioactivity & $11^{\text {th }}$ \\
\hline Mahmut & EPC & 47.46 & $\begin{array}{c}\text { Modification } \\
\text { mutation }\end{array}$ & $8^{\text {th }}$ & 46.44 & $\begin{array}{l}\text { Particle } \\
\text { nature of } \\
\text { matter }\end{array}$ & $6^{\text {th }}$ & Evolution & $12^{\text {th }}$ \\
\hline
\end{tabular}

* Time shows the duration of the course given by the teacher.

** PES: public elementary school, PrES: private elementary school, PHS: public high school, EPC: private exam preparation centre 
Table 2. Codes and categories for basic instructional strategies used by the participants

\begin{tabular}{|c|c|c|}
\hline $\begin{array}{l}\text { Categories- } \\
\text { argumentation } \\
\text { process }\end{array}$ & $\begin{array}{l}\text { Instructional strategies } \\
\text { derived from the literature }\end{array}$ & $\begin{array}{l}\text { Instructional strategies used by the } \\
\text { participants in this study }\end{array}$ \\
\hline $\begin{array}{l}\text { Challenge the } \\
\text { correctness }\end{array}$ & $\begin{array}{c}\text { Rephrase and address question } \\
\text { to other group } \\
\text { Asks for elaboration }\end{array}$ & $\begin{array}{c}\text { Asking for further arguments } \\
\text { Clarification of an argument/ claim(s) by } \\
\text { questioning and/or rephrasing } \\
\text { Clarification of counter positions for further } \\
\text { argumentation by questioning and/or rephrasing } \\
\text { Clarification of justification/ a rebuttal by } \\
\text { questioning and rephrasing }\end{array}$ \\
\hline $\begin{array}{l}\text { Constructing } \\
\text { arguments }\end{array}$ & $\begin{array}{l}\text { Uses writing frame or written } \\
\text { work/prepares } \\
\text { presentations/gives roles }\end{array}$ & $\begin{array}{c}\text { Constructing a problem/ a case for argumentation } \\
\text { Drawing a writing framework to construct an } \\
\text { argument } \\
\text { Providing instructions for an activity } \\
\text { The role of the students }\end{array}$ \\
\hline $\begin{array}{l}\text { Counter arguing/ } \\
\text { debating }\end{array}$ & $\begin{array}{c}\text { Encourages debate } \\
\text { Encourages anticipating } \\
\text { counter-argument }\end{array}$ & $\begin{array}{l}\text { Questioning for further arguments/ claims } \\
\text { Questioning to elicit arguments } \\
\text { Initiating argumentation } \\
\text { Encouraging counter arguments }\end{array}$ \\
\hline $\begin{array}{l}\text { Evaluating } \\
\text { arguments }\end{array}$ & Process - using evidence & $\begin{array}{c}\text { Encouraging the use of } \\
\text { data/observation/information as evidence }\end{array}$ \\
\hline $\begin{array}{l}\text { Extending range of } \\
\text { topic }\end{array}$ & Asks for elaboration & Expanding a claim \\
\hline $\begin{array}{l}\text { Involve more } \\
\text { students }\end{array}$ & $\begin{array}{l}\text { Address question to individual } \\
\text { or group }\end{array}$ & Asking for an argument \\
\hline $\begin{array}{l}\text { Justifying with } \\
\text { evidence }\end{array}$ & $\begin{array}{c}\text { Checks evidence } \\
\text { Prompts justification } \\
\text { Plays devil's advocate }\end{array}$ & $\begin{array}{c}\text { Appealing to evidence } \\
\text { Asking for justification } \\
\text { Playing devil's advocate } \\
\text { Proposing (a) claim(s)/ counter-claim/ alternative } \\
\text { claim(s) } \\
\text { Proposing a counter-argument/ alternative } \\
\text { arguments } \\
\text { Proposing an alternative justification/ a counter- } \\
\text { evidence/ a rebuttal } \\
\text { Providing evidence as experimental data/ figures/ } \\
\text { pictures/graphs/ scientific information/ } \\
\text { statements }\end{array}$ \\
\hline Positioning & Values different positions & $\begin{array}{l}\text { Drawing attention to position/ counter position/ } \\
\text { dilemma } \\
\text { Guiding students to alternative arguments }\end{array}$ \\
\hline
\end{tabular}




\begin{tabular}{lcc}
\hline $\begin{array}{l}\text { Categories- } \\
\text { argumentation } \\
\text { process }\end{array}$ & $\begin{array}{c}\text { Instructional strategies } \\
\text { derived from the literature }\end{array}$ & $\begin{array}{c}\text { Instructional strategies used by the } \\
\text { participants in this study }\end{array}$ \\
\hline & Encourages ideas & $\begin{array}{c}\text { Encouraging the consideration of } \\
\text { alternative/opposite ideas } \\
\text { Encouraging more arguments }\end{array}$ \\
\hline $\begin{array}{l}\text { Reflecting on } \\
\text { argument process }\end{array}$ & Asks about mind-change & Asking for mind-change \\
\hline $\begin{array}{l}\text { Talking and } \\
\text { listening }\end{array}$ & $\begin{array}{c}\text { Encourages discussion } \\
\text { Encourages listening }\end{array}$ & $\begin{array}{c}\text { Encouraging argumentation } \\
\text { Encouraging listening } \\
\text { The role of the teacher }\end{array}$ \\
\hline
\end{tabular}


Table 3. Codes and categories for meta-level instructional strategies used by the participants

\begin{tabular}{|c|c|c|}
\hline $\begin{array}{l}\text { Categories of } \\
\text { argumentation processes }\end{array}$ & $\begin{array}{c}\text { Instructional strategies } \\
\text { derived from the literature }\end{array}$ & $\begin{array}{l}\text { Instructional strategies used by the } \\
\text { participants in this study }\end{array}$ \\
\hline \multirow[t]{5}{*}{ Evaluating arguments } & Evaluates arguments & Developing a rubric as assessment criteria \\
\hline & & $\begin{array}{c}\text { Developing an assessment strategy for an } \\
\text { argumentation lesson }\end{array}$ \\
\hline & & $\begin{array}{c}\text { Drawing an evaluation framework for } \\
\text { justification }\end{array}$ \\
\hline & Setting expectations & $\begin{array}{l}\text { Setting expectations for students' learning } \\
\text { about argumentation }\end{array}$ \\
\hline & & $\begin{array}{l}\text { Setting expectations for the quality of } \\
\text { argumentation }\end{array}$ \\
\hline Focus on debate technique & Drawing rules & $\begin{array}{l}\text { Drawing rules for a teaching } \\
\text { method/strategy }\end{array}$ \\
\hline \multirow[t]{3}{*}{$\begin{array}{l}\text { Knowing meaning of } \\
\text { argument }\end{array}$} & $\begin{array}{c}\text { Choosing/naming a specific } \\
\text { strategy }\end{array}$ & $\begin{array}{c}\text { Choosing a specific strategy to implement } \\
\text { argumentation }\end{array}$ \\
\hline & & $\begin{array}{c}\text { Naming a specific strategy to implement } \\
\text { argumentation }\end{array}$ \\
\hline & $\begin{array}{c}\text { Identifying objectives/ } \\
\text { purpose }\end{array}$ & Defining the objectives of a specific strategy \\
\hline
\end{tabular}


Table 4. Codes and categories for meta-strategic instructional strategies used by the participants Categories of argumentation processes as reflected in Instructional strategies used by the teachers' contributions participants in this study

Drawing rules for a thinking strategy

Constructing arguments

Modelling the thinking strategy

Constructing arguments

Coordinating evidence

Providing justification

Naming the thinking strategy

Constructing arguments 